\title{
DARE TO CARE
}

\section{A philosophical discussion about the virtue of courage among care home managers}

\section{The virtue of all or a few}

Some of the central questions of the virtue ethics theory remain to be tackled, prompting lively discussions such as: "What is the list of the virtues that one character ought to develop? Is that list finite? Are we talking about a period of "proliferating virtues"?' Are there some cardinal and fundamental virtues that should not be ignored in any list? Is there unity between virtues? What virtues are specially cultivated in specific domains of activities and what happens if we are not participants in those activities? How, where and why should we develop those character traits?"

Some of these questions will be raised, and, only partially for some, answered while discussing the virtue of courage at the workplace.

The word courage can be attributed in descriptions of everyday life conversations to a bad character, however, here courage is considered to be a moral term, and as such requires, for example, the presence of the virtue of prudence and understanding of the good that one is carrying and trying to attain. If one cares about their family, friends, neighbourhood, etc., that particular care gives the agent desire and passion for employing courage. If something is worthless, then the agents do not have good reasons to sacrifice their wellbeing for nothing. However, even if something does deserve our bold intentions, how can we find the desire to take ourselves out of the comfort zone and into the field of risk and the unknown? There must be something in it that we profoundly care for. Moreover, caring is an action, rather than a warm feeling or rational appreciation of a valuable principle.

* Dr. sc. Anita Calvert, Faculty of philosophy and religious studies, University of Zagreb, Jordanovac 110, 10000 Zagreb, Email: anita@trevlac.co.uk

1 Nancy Snow held a lecture on the 27th October 2017 at the Margaret Beaufort Institute of Theology in Cambridge titled Proliferating Virtues where she raised questions such as do we have to always change lists of virtues according to the changes in the world, environments and circumstances we live in? 
And this is what this paper is all about - how the concept of care influences the understanding of the virtue of courage.

Many people believe that courage is the virtue of only a few, expressed in extreme cases when confronted with life or death situations, such as do fire-fighters, the police, marine forces or soldiers. Interview with managers of care homes (see below) about the virtue of courage provoked surprise among themselves, because, generally, because their work is not considered as an act of bravery. "I would say fire-fighters can be courageous. They are walking into burning buildings. I am not" (manager CBEEP). However, talking with care home managers one can understand that they do feel lots of burning flames from their clients and their family members, the Care Quality Commission (CQC) reports, staff and their own desires to accomplish intended goals.

Philosopher Douglas Walton wrote the book Courage. A Philosophical Investigation in 1984 wherein he seems to support the proposition that courage happens only on rare occasions. According to him, courage needs to fulfil these condition: 1. Careful presence of mind and deliberate action; 2. Difficult, dangerous and painful circumstances; 3. A morally noble intention, implemented in an altruistic act to save the lives of others; 4 . The agent's personal risk and suffering. (Walton, 1984, p. 3) So rather than naming the agent "brave" or "courageous" in a too subjective manner, courage is the property of the individual action, not the agent.

Furthermore, in Walton's opinion, alongside with virtues such as generosity, mercy, politeness, courage also belongs to the category of supererogatory actions that result in outcomes beyond the expected. So as for any supererogatory act, also for any courageous act, it follows that (Heyd, 1982, p. 115): 1. It is neither obligatory nor forbidden; 2 . Its omission is not wrong and does not deserve sanctions or criticism; 3. It is morally right, both under its (intended) consequences and under its intrinsic value (being beyond duty); 4. It is done voluntary for the sake of someone else's good and is; thus; meritorious. Superheroes are called super because of this extraordinary quality of being brave despite their inner fears and external obstacles. Not everyone is invited to be courageous. From that point of view, we are not all obligated to do brave deeds (at work); it is praiseworthy, but it depends entirely upon our desires, will and, ultimately, our own developed character.

Courage, on the other hand, can be understood as an underlying everyday character trait that enables us to do anything in the right way. Aristotle and Aristotelians understand courage as developing virtue from the young stages of life in everyday activities in continuous exercises. Likewise, existential writer Paul Tillich says in his book, The Courage To Be, that it is implicit that courage is a continuous affirmation of life on the ethical and ontological level and that courage is fundamental "yes" to life despite all its 
imperfections. Tillich wished a strength and an existential kind of courage for people in the period shortly after World War II, when he wrote the book, to fight against an omnipresent nihilistic depression attitude with which human minds were then so engrossed. His voice called out for the building up of different kinds of courage in the period of societies building peace and constructing their everyday living. "The coward, then, is a despairing sort of person; for he fears everything. The brave man, on the other hand, had the opposite disposition; for confidence is the mark of a hopeful disposition" (Aristotle NE, 1116a, pp. 1-5). Courage is a human disposition to act in a life-affirmative way. According to Aristotle, brave people are motivated by

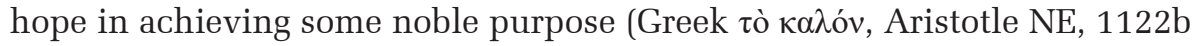
pp. 6-7); at the same time, he says hope is an expectation of good, while, as Tomas Aquinas added, fear is an expectation of evil (Thomas Aquinas, Commentary on the Nicomachean Ethics, Lectio XIV, p. 530). Surely, our practical reasoning while screening all of the particular circumstances will fortify the expectation of a good or a bad outcome, but, despite low statistical chances, we can still act in a life-affirmative way. If, and only if, there is something valuable or noble to be worth putting oneself at risk. "In cases, where nobility is abandoned for victory's sake, courage is abandoned, too" (Rogers, 1994, p. 306).

It would be left to pure luck to take courageous actions only on rare occasions if they are not practised in everyday life activities. If one decides to remain silent while watching somebody else being bullied at work, how can we expect one's engagement in a defensive war case scenario? In daily activities, we are confronted with many fears and obstacles to achieve our goals and those help us to act in the same mode when there is a life-threatening situation. If we omit to do a brave deed, a) we omit to acknowledge the good purpose of that action, and b) we are giving in to our inner fears. If we have fallen into despair and are unable to act towards an indication of our judgements, then c) we are ignoring the true state of affairs, d) we ignore our arguments, e) we ignore what is just, we ignore what is noble. And, by diminishing epistemological and moral awareness of ignorance, the coward significantly diminishes his/her personal development. By that reason, courage is not extraordinary, a supererogatory act, it is a basis to do anything in the right way.

Whether the place where we work functions as a proactive factor to develop the virtue of courage or not is a question of another kind, Scottish philosopher Alasdair MacIntyre stressed the importance of the structure of working ambient to cultivating certain virtues. 


\section{Developing virtue of courage in the workplace. alasdair macintyre's thoughts as a helping hand to understand traits of courage}

in a society with no current wars on the doorstep, the images of courage can be found among those people who are striving to achieve various kinds of goals. We are praising people who are making things happen. Agents. And, if there are types of characters in societies who represent moral idols (in MacIntyre's opinion these characters in a liberal society are psychotherapists, aesthetes and managers), surely managers represent people who make things happen. In a time of peace in a liberal culture, managers represent one of the significant images of courage. They are standing up against the obstacles, if necessary against rather than for the crowd, they follow their convictions and finalise them out of a pure idea to vivid desired outcomes. Managers are the driving force behind the mechanism. They are the "pushovers" over the procrastination, incompetence, ignorance, local agreements, common views or just bad luck that causes a breakdown in the chain of activities leading towards outcomes. However, focusing only on the outcome is not enough. A project manager, for example, trained widespread and sought for the Prince2 UK Government study programme, needs to be focused on outcomes, on results, on the desired products. That product could represent the common good of the society, but the principles of the Prince 2 method approach do not require consideration of that moral concerns. The manager and the project team need to focus on the outcome, not the process that provides, not the people and their accompanying development. Out of the seven principles involved in managing the Prince2 project, none of them not even slightly approaches the idea of employees' development and a specific understanding as to what good we are committed to while creating this project. And that is not enough, at least not for an Aristotelian kind of manager of excellence.

The choice of the workplace is vital for something more than just a carrier, a knowledge and a skill set progress. It is a decision that impacts on overall moral character development. Just as we train our specific craft skills, Aristotle held the opinion that we build a good moral character throughout the constant exercise of virtues. One can learn to appreciate the knowledge and experience gained in training skill for reaching project goals because, to develop virtue, one needs to go through a similar process. Similarities between developing a skill and a virtue should not be taken straightforwardly, however. (Russell, 2015). Despite the fact that skill does not have moral evaluation, Lapsley and Narvaez noted a similar path: "becoming virtuous, like becoming skilled, is a matter of having certain goals and values in terms of which to focus one's attention on one's environment; it is a matter of 
learning how to focus that attention effectively so as to extract information relevant to those goals and values, and it is also a matter of learning enough about how the world works to process that information so as to formulate intelligent plans and adjust one's behaviour accordingly" (Lapsley and Narvaez, 2004, pp. $200-201$ ).

MacIntyre emphasises the relevance of awareness in developing both, skills and virtues, spontaneously and simultaneously. The person who has developed a skill to reach desired goals, inspired and focused only by the given description of the outcome of the project and who is concerned foremost for the efficiency of their actions, applies to something that MacIntyre named "the courage of efficiency" (MacIntyre, 1988, p. 41). On the other hand, "courage of excellence" applies to the developed virtue of the person who is trying to develop their character while being engaged in creating the inner good of practice. Flourishing is equally important. And not simply because employees will be more productive if they feel good about themselves and are content. An Aristotelian kind of moral expectations requires personal development in any working involvement. The goal is to achieve excellence, in what we do and in ourselves, this is why this ability is called "courage of excellence". MacIntyre, however, names both "virtues", — the skill as "courage of effectiveness" and virtue as "courage of excellence", in his book Whose Justice, Which Rationality? Although he is the one that apostrophes the relevance of the different descriptions. Ancient understanding of the Greek word arête also encompasses both meanings, moral virtue and skill to do something in the right manner. For the sake of the discussion, it is good to use different categories in referring to these, either to skills or to virtues.

MacIntyre believes that, in order to develop virtue, one needs to be involved in a work that has been formed as a "practice". In his words, practice is "...any coherent and complex form of socially established co-operative activity through which goods internal to that activity are realised in the course of trying to achieve those standards of excellence which are appropriate to, and partially definitive of, that form of activity, with the result that human powers to achieve excellence, and human conceptions of the ends and goods involved, are systematically extended" (MacIntyre, 2007, p, 187). People can work either in practices or institutions. People participating in practice are, as described above, concerned about and care for the inner goods of the practice (those goods by which the practice can justify the reasons for its existence, such as a catch of fish is an inner good of fishing, inner good of care home is excellent care for residents), while people involved in institutions are concerned about amplifying the external goods (power, wealth and fame). Practices are places of creating goods for society and are always under the threat of being corrupted by the goals of those working in institutions. The organisation is composed out of institutional and practice 
level, and practice does need external goods to sustain the inner goods of practice. The issue arises as to whether dedication to the inner goods of practice is distracted by the methods of accumulating external goods, such as wealth, power and fame. External goods enable the practice to be maintained, but focus on them weakens the practitioner in achieving high standards of his/her skills and virtues. Why? External goods such as money can be achieved in manifold ways. Inner good, for example, growing fresh lettuce, can be achieved only by the highest standards in planting lettuce and caring for the environment; likewise, safe and flourishing older adults can be achieved only in carrying out environments with the highest respect of standards of excellence. If the external goods are prioritised above the inner goods of practice, then the standards of the practice can quickly become questionable. If the practitioner does not care enough about the inner goods of practice, one can start to look for some other ways of receiving external goods. If a person is involved in the activity in order to receive a high salary, then she/he sees manifold ways of achieving that goal. If the person believes that the goods of practice are a necessity for the community (or sometimes just for an individual), they are striving to achieve those goods while understanding their purpose. Their steadiness towards the specific inner goods are intensified, and that exclusiveness makes them bold towards not this or that activity, but the best possible activity according to the high standards of employment. That is how the courage of excellence is practised, and this is how other virtues such as justice and truthfulness are becoming tools to resist the corrupting powers of institutions. (MacIntyre, 2007, p. 184) MacIntyre's teleological approach to virtues, unlike Aristotle's, has a clear image of the purpose of our activities. He praises Aquinas' teleological approach above Aristotle's because Aquinas clearly stated that that good that we see as a final purpose of our deeds is God. And, here, MacIntyre says we can clearly understand what is right, firstly by looking at the practices that society needs and supports. On the second level, we question whether that good of practice is in accordance to the comprehension of a good for our own, personal life story and, thirdly, we question whether we agree with the concept of a good for human life such as supported in our tradition. These are not abstract, but vivid goods that attract our actions, 1) inner goods of practices in which we are involved, 2) goods for narrative unity of our life and 3) goods of tradition. Open discussion and deliberation about these goods, as well as personal choice and acceptance of inner goods of practice are sine qua non, so they can become a part of the personal desire and care that one wants to pursue. Do persons genuinely care for those goods that they are fighting for at work?

Managers are in charge of the institutional level of an organisation, respectively supplying practices with the external goods, also requiring a bal- 
ance between the claims of internal and external goods in organisational life (Beadle, 2013). If this so, then the organisation should operate as a practice-based community, in which practices and the virtues they care for are characteristically protected from the distorting potential of external goods (Beadle and Konyot, 2006). As managers are initiators and creators of working atmospheres, more than the other participants of the organisation, if they prioritise the inner goods of practice rather than gaining money, the others might follow. They have direct responsibility to make and implement decisions into a system of daily assignments and have a vital influence on other employees' understandings of how things should be done. Regardless as to whether some virtues are highly respected or utterly ignored by managers, the impact of their moral standpoints remains. The outcome of the influence, though, is not straightforward. Dictatorship-like management might provoke the development of followers' cowardice among employees, or it might inflame the development of courageous spirits.

Furthermore, a manager's dishonesty might encourage dishonesty among the rest of the working team, or it might trigger particular sensitivity towards that vice. Managers' character and worldviews affect the moral considerations and judgements of the working environment in a more common and distributive way. Those are reflected in conversations, comments and discussions among workers focused on, for example, what is right, just and fair (un/just manager) rather than what is truthful, dishonest, naïve (dis/honest manager), or what it means to be weak, rash, bold, coward, fearful (not/brave manager), etc. In management with a lack of courageous leadership, employees are concerned and reflect more upon what should have been done and was not, how obstacles could have been avoided, whether they were fighting for meaningless goals rather than why they have not been introduced to relevant or facts, what is the purpose of being brutally honest or deceitful, etc.? And, although every employee participates in the creation of a working environment, a manager's behaviour has a more significant influence because their opinion has been broadly communicated to the employees.

In a situational ethics approach, taken, for example by Doris (Doris, 1998, 2002), virtues are conceptualised as behavioural regularities that are indexed to the objective features of situations. We do agree to the degree that the situation at work can influence a person's moral character, but still recognise great possibility to overcome those situational frames with individual habitual tendencies. Managers influence the creation of a working ambient considerably and are in, some way, more responsible for morale at the workplace, more so than the rest of the members of the working team. That does not mean that a non-manager role cannot be leading example of moral behaviour. 
Furthermore, there is something about the industry a person is working in that makes one think in a certain way. In a finance-oriented industry, high quantitative outcome stipulates high standards of efficiency and supports the cultivation of those kinds of virtues which will enable a person to act efficiently. Rationality, distributive justice, assertiveness, confidence, integrity, moderation and reliability are all virtues essential to develop a financially efficient mode of thinking. On the other hand, a caring industry revolves around the development of those virtues that could provide a caring atmosphere at work, such as compassion, tolerance, courage, humility, honesty, respect and patience. As in other ambient, so in a caring ambient all virtues in practice will develop in a form appropriate to the inner goods of that practice. In that sense, courage will be developed as the courage of care rather than the courage of efficiency. In MacIntyre's term, the courage of care would belong to the category of courage of excellence, as mentioned above, because it supports accomplishment of the inner goods and the care for clients according to the standards of the excellence of practice. That does not mean that each care home develops the courage of care, but that it ought to and, where there is the courage of efficiency in practice, then the standards of efficiency are set above the standards of excellence. Again, the courage of efficiency belongs only to the category of a "skill", not a moral virtue.

MacIntyre's moral philosophy helps us on the path to understanding that if courage is being developed as a virtue, then it is highly influenced by working setting that people choose in their everyday life. Also, it helps us to understand why the character of the managers are relevant to understand the features of courage understood and practised in the working domain. For this study, it is appropriate to mention MacIntyre's unique view on the correlation between notions of care and courage.

In his classic work, After Virtue, Alasdair MacIntyre relates courage with the "care and concern for others" and repeatedly remarks that courage is one of the vital virtues. Without courage, participants in practices could not resist the temptations of the external goods that institutions are in charge of and could not maintain integrity in keeping one's own life stories as an individual and not just random stories that happen to us (MacIntyre, 2007). Courage is a fundamental attitude that gives personal identity opportunity to stand against situational commodities. MacIntyre talks about the courage as a trait that needs to be developed in societies to keep its tradition alive and keeping it alive means having the courage to involve oneself and others in arguments about what society should care and regards as a good for human life. In the paragraph below, MacIntyre explains how individuals in society test what is worth fighting for:

We hold courage to be a virtue because the care and concern for individuals, communities and causes require the existence of such a virtue. If someone says that he cares for some individual, community or cause, but is unwilling to risk 
harm or danger on his, her or its behalf, he puts in question the genuineness of his care and concern. Courage, the capacity to risk harm or danger to oneself, has its role in human life because of this connection with care and concern. That is not to say that a man cannot genuinely care and also be a coward. It is in part to say that a man who genuinely cares and has not the capacity for risking harm or danger has to define himself, both to himself and to others, like a coward. (MacIntyre, 2007, p. 192)

The job description of care home managers involves managing and dealing with numerous kinds of risks, of their own and others, staff and residents. How difficult must it be for a manager to allow someone whom they care for to be involved in risks? How can managers develop the courage of care and not the courage of efficiency even though they are working at the institutional level of an organisation? How do managers of care homes perceive the virtuous character and what is their concept of courage in regards to involvement in the risks? In order to understand these and similar issues, a series of interviews were carried out among the managers of care homes for older adults, from December 2016 till March 2017 in Kent County in the United Kingdom. ${ }^{2}$ As the interviews followed qualitative methods of research, discussions were used as an insight into a new perspective on the concept of courage of care and complex relation between involvement in risks and care for others.

\section{The concept of courage among the care home managers in Kent}

the interviews began with asking participants whether they have any traditional background other than English that would influence their worldviews. The majority of them merely stated that they were English and just a few reported some other influences (for example Scottish, Jewish, Indian), but did not recognise any radical difference because they had lived in England for a long time. So, concerning tradition, the views expressed among care home managers are influenced by English culture and its values.

In order to put participants in the right frame of mind, they were given, at the start of the conversation, a sheet of paper with the table of sixteen virtues out of which they needed to choose the five they valued the most in the working environment and, separately, five virtues in their personal life circumstances. Methodically, this initial approach has its positive and negative arguments. Negative, since it imposes the manager's awareness of the sixteen virtues that we have listed and brings out from the subconscious, in

2 The approach of qualitative research study has gained Ethics Committee Approval at the Heythrop College, the University of London and informed consent was obtained from all individual participants included in the study. 
most cases, only those virtues that we have selected. On the other hand, in the process of preparation before the interviews with the managers, persons who had been asked to describe a moral character found it difficult to operate and express themselves in terms of virtues, so the list was a helpful tool. However, the virtue of courage is a good example in that these managers were not easily influenced by the emphasis of others because, despite the description and title of the research contained 'the virtue of courage' in the official invitation letter sent to participants, not all of them ticked courage as one of the most valuable virtues.

After handing back their hierarchy of virtues, they were asked to describe in their own words the character of a perfect care home manager and the character of a perfect employee. Managers gave priority and stressed high respect towards two virtues - honesty and compassion. Manager CBEL1 said: "When I employ somebody, hire somebody, I always ask them to be open, to be honest. Simple example, when I employ somebody, they will say they can do almost anything, and I am available full time. I can do that and that... Just be honest! What CAN (interviewer emphasis) you do?" This kind of honesty at a job interview, however, can be straightforwardly linked to courage. Even though a person could risk not getting the preferred employment, one needs to be brave enough to stay strong in their beliefs. The virtue of compassion is, on the other hand, closely related to this kind of profession. In the description of the perfect employee, manager CBET1 said: “...very caring nature, that would be my top ... Skills, the knowledge that all can come after. I think that if somebody has a naturally caring nature, the rest will follow." Talking about a perfect manager, CBES1 said: “... having a great empathy and being assertive but in a compassionate way." Comparing the list of the virtues that the managers of care homes ticked in their working environment and those in personal life, it is indicative that the virtue of compassion was picked out without exception for the working community since they consciously or subconsciously relate compassion and care to their profession. ${ }^{3}$

While honesty and some others, such as accountability, were also mentioned several times as essential traits, these are character traits that support the efficiency of the organisational system and are useful for achieving external goods, while the virtue of compassion is developed by caring for the inner goods of practice, in these environments, namely, caring for elderly people. Thoughts about compassion and care occupy their minds. One of

3 Since this is a research done by qualitative method about courage, this could be only an indication of a relationship, but it would be interesting to confirm this statements in further research, either with the quantitative method using the same list of virtues to do comparative analyses in different professions' environments or to do qualitative in-depth interviews in care homes on the subject of virtue of compassion. 
the participants explained the purpose of having care homes in society as follows: CBEEP: "People are not just put here because people don't want to remember them and they don't care. It's quite the opposite! They want them here because they CARE (interviewer emphasis) and they want to make sure they are being looked after. Things like giving them medication that they would of forget, it can be life-threatening."

While we spoke about care, the term "care" was used as a form of activity while "compassion" was used as a character trait, a virtue of a care worker and, in general, a feature of a working community in care homes. Giving care is a carer's working duty while giving compassion is a personal option. Chris Frakes is the author of an interesting article about care, justice and compassion that has been published in the journal Hypatia (Frakes, 2010). She starts the text by explaining how she before her research used to work for a women's shelter and while caring for and seeking justice for threatened women, she had developed her depression. Emotionally drained, Chris Frakes started to look for answers and found one in a proper kind of giving compassion. She writes: "Although I am persuaded that the virtue of justice can moderate the partiality of care, I am not persuaded that care or justice adequately motivate attention to the suffering of strangers; rather, another virtue, the virtue of compassion, is necessary. I suggest that the virtue of compassion, rather than the virtues of care or justice, allows the agent to sustain her engagement with suffering strangers without suffering her own flourishing." (Frakes, 2010, p, 80) Related to this issue, in our research, one of the managers of care homes explained how she understands what courage is. CBEL22: "I think it could be people just facing their fears, I think that is courageous, what we are doing with lots of clients who are at the end of life. So, I think that is a situation that people need lots of courage sometimes. ... I think that it is very difficult to face. The staff need to be strong for the residents sometimes." Being confronted with the harm and distress of the others, one confronts oneself with the inner distress and pain. To overcome the obstacles and show the care, courage is needed. As MacIntyre stressed, one can feel compassion and do nothing, but then that one is considered a coward or can show an explicit kind of care and do the brave thing, despite one's distress. Dare to care.

Research in moral psychology (Gibbs et al., 1986) suggests that the development of a courageous trait is closely related to a child's ability to understand and express compassion in society. Brave children will help out their little friends in need if they are capable of feeling their pain. And that is what differentiates compassion from sympathy, which is (only) a positive reaction to other people's feelings (Slote, 2015). A child that can feel the pain, to be in distress if their friend or a stranger suffers, shows compassion. 
However, to show that compassion, courage is needed, rather than feeling sympathy in a quiet corner.

Furthermore, it is not enough to know some practice in order to have the initiative to do the right thing. Francoise Baylis, in the article Health Care Ethics Consultation, Training in Virtues, explains that healthcare ethics consultants sometimes lack courage, because, despite the fact that they are "responsible for teaching and engaging in formal ethics analysis, it doesn't follow that they will always have the courage to act on their convictions." (Baylis, 1999, p, 33) In those terms, the same as for healthcare ethics consultants as for care home managers, the distinction elucidated by Gilbert Ryle's Knowing-How and Knowing That (Ryle, 1971) is actualised explicitly with the workers without courage. Having expertise does not mean one dares to put that expertise into practice, to experience it by being brave. Hence, excellence in practice develops together with the evolving training in the virtue of courage.

Care home managers, as leaders of a practice-based organisation, also talked about the courage of being aware of the institutional hierarchy they are in. Being in charge of external goods created an additional challenge for them, compared to the care workers, because they had to fight for inner goods of practice prior to the beneficial rewards. For example, manager CBES11 said: "I think sometimes it feels like swimming against the tide, especially when you work for the big organisation and having the courage to stand up and say: 'You know what? This is not how we should be doing it.' ...being in big corporate courage sometimes gets a bit squashed out." Furthermore, participant CBET1 said: "I think the way you work your way up through the ladder, confidence and courage run next to each other. And as you gain in the knowledge you gain in confidence, therefore, the courage comes along with that as well...as you are working your way up you may have your ideas, things you may want to do, and you might have the courage do it, but whether you have permission to do it is a different thing, so you get barriers." Here, we have an expression of a belief that courage is applicable in a different way to higher level positions in the organisation because it gives the opportunity to the worker to make their own decisions and pursue them. This manager used to be a care worker and now runs her own private care home, so she did not have to be responsible to the owners such as, for example, manager CBEL1. He explained that cowardice means simply following the instructions of a higher instance hierarchy: "I think when there is pressure from above, and they are doing just what the company wants ... I will give you an example. Some of the families are not able to fund the full amount. I have pressure from the director to take that full amount. So, I think it takes courage to help the family out or to say you have to be replaced ...if you have some principles, values and if you are not 
following what you believe is that value and listening to other people, you are acting like a coward.” There is present tension between satisfying both, giving the best of care, achieving the best inner goods of practice despite the beneficial rewards, and still managing to receive those external goods (institutional level). In asking manager CBES22 what her image of courage was, she replied: "I would pick someone like Winston Churchill. He, as a character, he stood up, he made decisions. Not everybody likes those decisions. And I think the world, the country I live in would be very different if he didn't pursue his convictions." Again, courage is thought of in respect of a hierarchy level, thinking about to whom one has to or does not have to justify own actions.

Some managers found it easier to describe what it means to be a coward in their work rather than being courageous. CBEEP1: "Walk away and leave other people to deal with the situations that you should be dealing with. That would be cowardice." Although this manager believes that she deals with the situations that she ought to, she does not believe she is courageous, since she thinks of courage, like Douglas Walton (see above), only in life-threatening situations. Therefore, in her mind, cowardice is not an opposition to bravery. CBEEP1: "I am thinking of something that I did that I have not liked doing it, but I did it." That was a test self-question for her courage, but she could not remember. The idea that courage is only for a specific group of people, such as soldiers and fire-fighters, was firmly set in her mind.

On the other hand, another manager, CBES22, explained courage as inner strength to deal with the difficulties in everyday life: "I think the courage, you can't always put into words. Sometimes it is less tangible. It's not that you always have to show the courage outwardly, it could be internal things. I think it is that ability, when life gives you difficult, horrible things, being able to cope with that, being able to deal with it. At the same time, make those decisions and take those risks, something about making a decision, taking risks and also having inner stability to make you able to do it, whether there are internal or external difficulties."

Inner stability is an essential feature in embracing the awareness of facing the unknown and unpredictable. If the person would know or would think they know what will happen, we would not talk about an admirable character trait as courage. When a person is aware that she puts hers and others' well-being at risk for the sake of achieving a greater good and remains where she believes she is supposed to be, that is a true sign of courage. Managing institutions does not mean having absolute control over of the processes, staff and clients' behaviour, even though that would be a much easier option. It is a conscious acknowledgement and acceptance of being publicly responsible for the risk-taking. And it takes guts to put that 
on your shoulders, especially when there is a possibility of physical and psychological harm to others involved. Here are some of the quotes from care home managers that revolved around the issue of taking responsibilities for the risk involvement of others. It is remarkable from their perspective that they allow their patients to take risks because they care for them, they care for their human dignity. CBET1: "You have to go to a certain point and recognise that they are people and that they have the right to do certain things. You can't wrap them in cotton wool. So you are allowing them to have a life and allowing them not to take all of the risks away, because if you take all of the risks that you might as strap them to the armchair and don't let them move and that is not what we do." CBES1: "I quite like engagement in risk. I allow residents kettles and microwaves. But 'Health and Safety' has taken over things, risks in the sense of moving things along. I am OK with risk-taking." CBEL1: "Letting residents do some things, with a high risk of fall, but you have to let them walk... Let them still do what they want, you do whatever you can do for them not to fall, and if it happens, they fall." Care is not controlling. It goes beyond because it comes from the virtue of compassion, which enables one to feel their desire to make their snacks and hot drinks, to have their car. Compassion with the courage to accept the risk involved for other human beings that one cares for, including that they could be possibly harmed, is surprisingly a proper kind of care for a human being. CBEC12: "As long the risk is fully explained, and the person is able to understand, then it has to be allowed... for a reason, of course, there are of course limits." CBES22: "I might not like it, but if they have the capacity, they have the right to make their decisions, even if it is unwise...But the line would be if there is something illegal and it would cause harm to somebody. Life is not straightforward. You can't avoid the risk, just manage it and make it a small as you can."

Contrary to attitudes expressed here among care home managers, Busenitz presented arguments that managers are less likely willing to deal with the risks compared to the other members of the working team (Busenitz, 1999). They manage the risks in order to reduce those risks to the lowest level so that they can carry on with their responsibilities. Conversely, managers of care homes understood involvement in risks as a part of everyday activities that cannot be avoided. Yes, they should be reduced to the minimum level, but they are part of every person's life. Prior to eliminating the risks, there is an apparent desire to give their residents a happy, homely and active environment.

Managers with high cognitive motivation observe, contemplate and discuss all relevant information, while those with low cognitive motivation usually make decisions based on own experience, suggestions and luck (Moorman, 1993; Foss and Pedersen, 2004;). As courage is a middle ground 
between cowardice and recklessness (Aristotle NE, 1104a, p. 20), rushing into risks without practical reasoning is a clear vice. However, figuratively speaking, "strapping residents to an armchair" with the comfort of no risks included, is an even worse vice because it supports a non-flourishing existence. Despite the laws and regulations, a manager's willingness to allow open space for self-initiative activities and creativity will be reflected in a whole working community and the goods they care for, flourishing elderly persons. That is why care homes are prime examples of how courage can be developed at the workplace as a universal virtue inspired by care for others.

\section{Conclusion}

although the virtue of courage is widely discussed as the disposition of putting oneself in the face of life-threatening danger for the sake of a noble cause, in order to be prepared and able to act in extreme circumstances, the virtue of courage is trained in everyday settings. Just as peace-building can be a much longer and challenging process than the process of destruction on the battlefield, so the process of developing a courageous character is full of demands and persistent efforts. Courage is an expression of a life-affirmative attitude towards obstacles to achieve a good that we care for. If a person continually fails to do brave deeds, then she is ignorant of her values, rational arguments and moral judgements. Thereby being a coward, a person impoverishes her abilities on all different levels. That is why courage is a fundamental virtue that enables us to do anything in the right manner.

Alasdair MacIntyre's suggestion that managers in liberal countries present one of the moral idols that people look up to has been addressed in this paper. Since, in time of peace, courage has been shaped by replicating the characters who are prepared to perform intended actions despite all obstacles in the way and managers are responsible and trained in methods to gain projects outcomes, they influence shaping the particular kind of courage in liberal countries. Following MacIntyre's inferences though, one could easily conclude that a manager is destined to develop the virtue of courage of efficiency, the type of skill that is required to achieve outcomes of an institutional level of organisation. But, despite the fact that the institutional level is there to provide external goods, such as money, power and fame for the whole organisation, a manager's awareness of a priority in achieving the inner goods of practice that the institution is based upon can prevail and twist the manager's inclinations towards a community of common goods. A manager who cares, above and beyond, for the inner goods of practice can develop the courage of caring for goods, whether material or immaterial, that the local society needs in order to survive and, beyond survival, to flourish. The moral attitude of the whole organisational team, the participants of practice 
and institution, are thereby influenced by the type of the industry they are working in and by the character of the managers they are led by. The way a manager understands and perceives risk involvement could create a significantly different working atmosphere. As training in virtues is somewhat like training in skills, the working environment can support either development of courage as a virtue, the courage of care, or courage as a skill, courage of efficiency. There is a rare clear intention of a manager to train hers/his staff in virtues, but the difference is evident if one's training is limited to gaining professional certificates and learning clear instructions about Health and Safety regulations, while lacking recognition of what is good for a person as a human being or lacking self-questioning of a working community. Devotion and steadiness in pursuing the highest standards of practice arise from care. Moreover, care, rather than being a mood or a temporary feeling, is a wide range of actions that express compassion towards vulnerable people or principles. The courage of care is an everyday expression of compassion towards the vulnerable in personally distressing situations despite the risks of the dangers. Carers in a care home need to stay strong and carry on with daily activities that acknowledge the human dignity of the residents, despite being confronted with the risk of harm and death. Stepping on mines is not the same as on the battlefields, because explosions can come from cooking a meal in an oven, skin can be burned, not by a fire or a bullet, but a steaming kettle, a broken leg does not need to be broken by treading into a trap, but merely walking. Despite all of these threats, life is to be lived with excitements and risks, as care home managers in this study stipulated.

It is easier to take the risk for solely oneself rather than to be accountable for the risk-taking of others of whom one is in charge, children, older adults with disabilities, people with illnesses. Being responsible for someone's care includes embracing the unknown and withdrawing from the idea of having absolute control. That is why care for someone must include possible harm of the cared subject. Otherwise, care could not be an impetus for brave behaviour.

However, being accountable for the risk-taking of others requires rational justification. In everyday activities, people have more time to deliberate about courageous decisions, rather than in occasions of an immediate threat, whereas people act in a habitual way that, again, they have gained in everyday life behaviour. When a person has more time to deliberate, it is more evident that courage is not rashness and it must go along with practical wisdom. Since, in care homes, there is a clear idea of what the common good working community cares for, it is easier to justify brave deeds. Some other industries with less obvious ideas of a common good, such as the stock exchange markets, require bold decisions, but it is difficult to justify them outside of a box of external rewards. One does not have to work in a caring industry to develop the courage of care, but one needs to understand is 
what the value that the working community cares and fights for. Courage is the virtue, not the skill that enables us to express in everyday settings and life-threatening circumstances that we do care for particular aims. It seems that we need to care for something to be motivated to dare, and, on the other hand, it seems that we are not caring if we are not daring. One does not come without the other.

\section{References:}

Aristotle. (1984). The complete works of Aristotle. The Revised Oxford Translation, Vol. I and II, edited by J Barnes. Princeton: Princeton University Press.

Beadle, R. (2013). Managerial work in a practice-embodying institution. The role of calling, the virtue of constancy. Journal of Business Ethics, 113(4), pp. $679-690$.

Beadle and Konyot, (2006). The men in the red coat - Management in the circus, Culture and Organization, 12 (2), pp. 127 - 137.

Busenitz, L.W. (1999). Entrepreneurial Risk and Strategic Decision Making. The Journal of Applied Behavioural Science, 35 (3), pp. 225 - 240.

Baylis, F. (1999). Health Care Ethics Consultation. Training in virtues. Human Studies, 22 (1), pp. $25-41$

Doris, J.M. (1998). Persons, Situations, and Virtue Ethics. Nous 32, pp. 504-530.

Doris, J.M (2002). Lack of Character: Personality and Moral Behavior. Cambridge: Cambridge University Press.

Frakes, C. (2010). When Strangers Call: A Consideration of Care, Justice, and Compassion Source. Hypatia, 25 (1), pp. 79-99.

Gibbs, J.C.Clark, P.M. Joseph, J.A. Green, J.L.Goodrick, T. S. and Makowski, D. G. (1986). Relations between Moral Judgment, Moral Courage, and Field Independence. Child Development, 57 (1), pp. 185-193.

Hanvelt, M. (2011). The Fortitude of the Uncertain: Political Courage in Hume's Account of the Public Sphere. APSA 2011 Annual Meeting Paper. Washington, American Political Science Association.

Heyd, D. (1982). Supererogation. Cambridge: Cambridge University Press.

Lapsley, D. K. and D. Narvaez (2004). A Social - Cognitive Approach to the Moral Personality. In D. Lapsley and D. Narvaez (eds.), Moral Development: Self and Identity. Mahwah, NJ: Lawrence Erlbaum, pp. $189-212$.

Lutz, C.S. (2012). Reading Alasdair MacIntyre’s After Virtue. New York, London: Continuum International Publishing Group.

MacIntyre, A. (1979). Corporate Modernity and Moral Judgment: Are they mutually exclusive?" In K.M. Sayre and K.E, Goodpaster (eds.), Ethics and Problems of the 21st Century. Notre Dame: University of Notre Dame Press, pp. 122-133.

MacIntyre, A (1982). Why are the Problems of Business Ethics Insoluble? In B. Baumrin and B.Friedman (eds.), Moral Responsibility and the Professions. New York: Haven. 
MacIntyre, A. (1988). Whose Justice, Which Rationality? London: Duckworth.

MacIntyre, A. (2007). After Virtue. A study in moral theory, 3rd ed. Notre Dame: University of Notre Dame Press.

Moore, G. and Beadle. R. (2006). In search of Organizational Virtue in Business: Agents, Goods, Practices, Institutions and Environments. Organisation Studies. 27 (3), pp.369 - 389.

Moorman, R. H. (1993). The influence of cognitive and affective based job satisfaction measures on the relationship between satisfaction and organisational citizenship behaviour. Human Relations, 46 (6), pp. 759 - 776.

Office of Government Commerce. (2009). Managing Successful Projects with Prince 2. Office of Government Commerce UK.

Rusell, C. D. (2015). Aristotle on cultivating virtue in N..E. Snow (ed.), Cultivating Virtue. Perspectives from Philosophy, Theology and Psychology. New York: Oxford University Press, pp. 17-49

Rogers, K. (1994). Aristotle on the Motive of Courage. Southern Journal of Philosophy, 32 (3), pp. $303-313$.

Ryle, G. (1971). Knowing How and Knowing That. In G. Ryle (ed.), Collected Papers Vol. II: Collected Essays 1929 - 1968. New York: Barnes \& Noble Inc.

Shimell, P. (2002). The universe of risk. How top business leaders control risk and achieve success, London: Financial Times.

Slote, M. (2015). The roots of empathy. In N.E. Snow (ed.), Cultivating Virtue. Perspectives from Philosophy, Theology and Psychology. New York: Oxford University Press, pp. $65-87$.

Schwartz, N.L. (2004). Dreaded or dared. Courage as a Virtue. Polity, 36 (3), pp. 341365.

Tillich, P. (2000). The courage to be. New Haven \& London: Yale University.

Thomas Aquinas (1964). Commentary on the Nicomachean Ethics (CNE) translated by

C. I. Litzinger. Chicago: Henry Regnery House.

Tondem, R., Burnes, B. and Oswick, C. (2012). Change Management. Leadership, Values and Ethics. Journal of Change Management, 12 (1), pp. 1-5.

Walton, D. (1986). Courage. A philosophical investigation. Berkley, Los Angeles, London: University of California Press.

Wrzesniewski, A., McCauley. C., Rozin, P. and Schwartz, B. (1997). Jobs, Careers, and Callings. People's Relations to Their Work. Journal of Research in Personality, 31(1), pp. 21-33. 
Abstract

\section{DARE TO CARE}

\section{A philosophical discussion about the virtue of courage among care home managers}

Paper is divided into two parts. The first contains two philosophical discussions about comprehension of courage and the second focuses on the findings in an empirical study with care home managers about the virtue of courage.

First discussion revolves around the question whether the virtue of courage is expressed a) only in life-threatening situations or is it a virtue trained and exemplified in b) everyday life settings, while the second emphasises the difference between i) courage of efficiency as a skill and ii) courage of excellence as a virtue. Arguments here support a vision of courage as the virtue of excellence expressed in everyday life settings.

The second part of the paper highlights a new perspective of courage with regards to the notion of care towards the aim of the courageous endeavour. The 'courage of care' supports the idea that the courage practised as the virtue of excellence aims to develop the moral character of the actor fundamentally outside of the life-threatening situation. Care for the self, other people, animals and intangible moral principles inspire us to do brave deeds. Thus, by accepting Alasdair MacIntyre's statements that a) in the times of the peace managers represent moral idols and b) idea that the notion of courage should be closely related to the practice of care and compassion, the research continued with the interviews with the care home managers in Kent county in England. Conversations with care home managers released further insights into how care and compassion influence the understanding of the virtue of courage.

KeYwords: Alasdair MacIntyre; care; care homes; compassion; courage; the courage of care; managers; skills; virtues. 